\title{
Influence of Plant Growth Regulators on Somatic Embryogenesis Induction in Seriphidium herba-album
}

\author{
Hemaid I. A. Soliman ${ }^{1,2}$, Fatma M. Abo-El-Hasan ${ }^{1,2}$, Ayman S. El-seedy ${ }^{3}$ and \\ Yasser M. Mabrouk ${ }^{3}$
}

\author{
${ }^{1}$ Plant Genetic Resources Department, Desert Research Center, El-Matariya 11753, Cairo, Egypt. \\ ${ }^{2}$ Tissue Culture and Biotechnology Labs., Maryout Research Station, Desert Research Center, Alexandria, Egypt. \\ ${ }^{3}$ Genetics Department, Faculty of Agriculture, Alexandria University. \\ *Corresponding author: Hemaid I. A. Soliman \\ hahemaid@yahoo.com Tel: +02010555772
}

\begin{abstract}
Seriphidium herba-album (syn. Artemisia herba-alba) is a medicinal, aromatic, greenish-silver herb. It is used widely in folk medicine for treatment of diarrhea, abdominal cramps and in the healing of external wounds. It's also used for the treatment of diabetes mellitus, neurological disorders as epilepsy, Alzheimer's disease, depression and jaundice. In this study we assessed the protocol for callus induction, maturation of somatic embryogenesis, frequency of germination and conversion into plantlets for leaf explants of Seriphidium herba-album using different concentrations of PGRs. Highest induction frequencies of embryogenic calli occurred after 35 days on MS medium supplemented with $1.5 \mathrm{mg} \mathrm{L}^{-1} 2,4-D$ and 0.5 mg $L^{-1}$ BAP. Optimum MS medium for higher frequency of matured somatic embryos was recorded using $5.0 \mathrm{mg} \mathrm{L}^{-1}$ BAP and $0.5 \mathrm{mg} \mathrm{L}^{-1} \mathrm{NAA}$ and somatic embryos also induced young in vitro grown plantlets when cultured in the medium containing GA3 and kinetin. Hence, attempts to induce direct somatic embryogenesis have been achieved up to embryo regeneration and maturation.
\end{abstract}

Keywords - Seriphidium herba-album, callus induction, somatic embryos, plant growth regulators (PGRs).

Abbreviations- BAP- Benzyl Amino Purine; GA3Gibberellic Acid; 2,4-D-2,4-di-chloro-phenoxy-aceticacid; MS - Murashige and Skoog medium; NAA - aNaphthalene Acetic Acid; Kn- Kinetin; PGRs- Plant Growth Regulators.

\section{INTRODUCTION}

Seriphidium herba-album (previously named Artemisia herba-alba Asso.) known also as desert wormwood (known in Arabic as shih, white wormwood, armoise herbe blanche). Seriphidium herba-album is a small perennial shrub native to northern Africa, western Asia,
Southwestern Europe, and the Arabian Peninsula, where it grows on dry steppes. It grows from 8 to 16 inches tall, is strongly aromatic, and is covered with fine glandular hairs which give it a grayish aspect (Segal et al., 1987; Nahla et al., 2011). Seriphidium herba-album is one of the most important medicinal plants that have been used in folk medicine for the treatment of gastric disturbances and healing external wounds, remission of diabetic symptoms, activating the function of the liver, and healing rashes, joint pains, inflammations and rheumatoid arthritis, with no side-effects (Feuerstein et al., 1986; Essawi and Srour, 2000). Moreover, experimental evidence showed that $S$. herba-album decoctions have beneficial effects as antioxidants as they contain compounds like tannins (Ben Abid et al., 2007). S. herba-album was found to have antifungal activity against Penicillium citrinum and Mucor rouxii due to the presence of carvone and piperitone isolated from the fresh leaves of the plant (Mahmoud et al., 2007; Boutkhil et al., 2011). The tissue culture of various Artemisia species of various Artemisia species is largely focused on improving artemisinin production. In vitro cultures of this species have been the object of great amount of research (Gulati et al., 1996; Nin et al., 1996; Honda et al., 2001; Liu et al., 2004; Sujatha and Rajnitha Kumari, 2007a; Mannan et al., 2008; Rezvan et al., 2010; Gopinath et al., 2014). It is widely known that plants from a natural resource or plants propagated by conventional means generally produce small quantities of secondary metabolites which makes their price very high; hence the studies on plant tissues and plant micropropagation offer various advantages for obtaining massive amounts plant material. The plant micropropagation is an efficient method for propagating disease-free and genetically uniform plants. It also appears that both liquid and solid shoot cultures are a good choice for micropropagation in 
laboratories because they reduce costs related to the automation of the procedure (Honda et al., 2001).The artemisinin production in shoot cultures of such species as A. pontica, A. judaica, A. vulgaris, A. scoparia, A. absinthium and $A$. annua was investigated by a number of researchers (Gulati et al., 1996; Pan et al., 2003; Sujatha and Rajnitha Kumari, 2007b; Singh and Sarin, 2010; Kour et al., 2014; Dangash et al., 2015). The present study is aimed to develop an appropriate and efficient regeneration protocol for the medicinal plant Seriphidium herba-album from leaf explants using different concentrations of PGRs for the first time, which has a high potential to be used in conservation and genetic transformation of this important medicinal plant.

\section{MATERIALS AND METHODS}

\section{Plant material and sterilization.}

Plant materials of Seriphidium herba-album were collected from North West coast of Egypt. The leaf explants were washed under running tap water for two hours. Surface sterilization was carried out under complete aseptic conditions in the Laminar Air Flow Hood by using aqueous mercuric chloride solution $\left(\mathrm{HgCl}_{2}\right)(0.1 \% \mathrm{w} / \mathrm{v})$ for 5 minutes, then rinsed once with sterile distilled water and transferred to $2.5 \%$ aqueous solution of sodium hypochlorite for 20 minutes at the end of sterilization treatment; the explants were rinsed 3-4 times with antioxidant solution. Sterilized explants were cut into leaf segments $(0.5-1.0 \mathrm{~cm})$ and implanted into sterilized media containing various combinations of plant growth regulators.

\section{Callus induction.}

Leaf explants were cultured on solidified MS medium containing 2, 4-D (1.0-2.0 $\left.\mathrm{mg} \mathrm{L} \mathrm{L}^{-1}\right)$ alone or in combination with BAP (0.5-1.5 $\left.\mathrm{mg} \mathrm{L}^{-1}\right)$. Media were solidified with $2.5 \mathrm{~g} / \mathrm{L} \mathrm{g} \mathrm{L}^{-1}$, subjected to $\mathrm{pH} 5.8$ before autoclaving $\left(121^{\circ} \mathrm{C}\right)$. A total of 12 different hormonal combinations were tested. The effect of the hormonal composition was evaluated by counting the calli obtained after 35 days of culture in the dark at $25 \pm 2^{\circ} \mathrm{C}$. Percentage of induced callus in each culture was evaluated as follows: Number of callus/Total number of explants x100.

\section{Somatic embryos induction.}

Induced primary somatic embryonic calli were sub cultured for further production of embryonic callus and their subsequent germination. Medium for induction of somatic embryonic callus, their proliferation and germination was conducted by transferring the somatic embryos into concentration of BAP alone or in combination of NAA and different complex additives. In defining the media composition, 15 different media containing BAP (1.0, 2.0, 3.0, 4.0 and $\left.5.0 \mathrm{mgL}^{-1}\right)$ alone or in combination with NAA $\left(0.5\right.$ and $\left.1.5 \mathrm{mgL}^{-1}\right)$ were tested separately for induction of somatic embryogenesis. Calli were incubated for eight weeks period in this medium. For germination of somatic embryos, MS medium supplemented with GA3 (1.0, 2.0 and $\left.3.0 \mathrm{mgL}^{-1}\right)$ in combination with $\mathrm{Kn}\left(0.5\right.$ and $\left.1.0 \mathrm{mgL}^{-1}\right)$ were tested. The culture was kept in growth room temperature at $25 \pm 2{ }^{\circ} \mathrm{C}$ with light intensity 3000 lux for $16 \mathrm{~h}$ photoperiod using cool white fluorescent lamps in the growth room for 8 weeks. Data were recorded as number and percentage of somatic embryogenesis formation.

\section{Statistical analysis.}

The experiment was carried out based on complete randomized design. Each of the experiments, excluding field performance study, was executed in five replicates with 20 samples per replication. For in vitro culture experiments, every single explant was treated as an experimental unit. Analysis of variance (ANOVA) was used to statistical analysis of experimental data using MSTAT Software (2009). Differences between individual means were estimated according to Snedecor and Cochran (1982). All values are reported as means \pm standard deviation.

\section{RESULTS AND DISCUSSION}

\section{Embryogenic callus induction.}

Source of plant growth regulator is an important factor for impacting callus induction, somatic embryogenesis and plant regeneration. In most cases, successful plant regeneration needs a mixture of the different auxin and cytokinin. Callus were produced in all media containing 2,4-D alone or in combination with BAP. A considerable variation in callus induction percentage and biomass of Seriphidium herba-album was detected in parallel with a mixture of the different auxin and cytokinin. After 35 days, the highest Callus induction percentage (95.44\%) was recorded with $1.5 \mathrm{mg} \mathrm{L}^{-1} 2,4-\mathrm{D}$ and $0.5 \mathrm{mg} \mathrm{L}^{-1}$ BAP (Table 1 and Fig. 1A). Highest value of relative water content (83.72) was recorded under treatment with $2.0 \mathrm{mg}$ $\mathrm{L}^{-1}$ 2, 4-D and $1.5 \mathrm{mg} \mathrm{L}^{-1}$ BAP under dark regimes compared with other treatments. The results stated that RWC is a contributing factor in nature of callus formation (friable and creamish green) data not presented. Similar results were reported by Anis et al. (2014) of Artemisia annua. They reported that embryonic callus induction was formed on MS medium supplemented with 2,4-D and TDZ. Dangash et al. (2015) found that callus induction from stem explant of Artemisia annua L. plant on MS medium containing BAP $\left(0.5 \mathrm{mg} \mathrm{L}^{-1}\right)$ and NAA $(1.5 \mathrm{mg}$ $\mathrm{L}^{-1}$ ). While, Nin et al. (1996) reported that no callogenic response from leaf explant on PGR-free medium and explants died after few days. 2, 4-D as callus inducing hormone produced light green, soft, friable and compact callus from leaf and stem explants. But at all concentration 
of 2, 4-D organogenic response was not observed within observation time. Etienne et al. (1991) stated that water status in the callus is apparently important for initiating somatic embryogenesis, and RWC appear to be good physiological marker of it embryogenic state.

Ganesan and Paulsamy (2011) observed $98.66 \%$ callogenic response from leaf discs with NAA at $0.9 \mathrm{mg} \mathrm{L}^{-1}$ in $A$. annua L. whereas Benjamin et al. (1990) observed callus induction from shoot buds using BAP plus IAA for Artemisia pallens. 2, 4-D at varying concentration (0.05$\left.0.25 \mathrm{mg} \mathrm{L}^{-1}\right)$ in combination with BAP $(0.5 \mathrm{mg} / \mathrm{l})$ also produced light green and soft callus when supplemented in MS medium. When IBA and NAA were combined with Kin, the callogenic response was also low and callus was not good in texture. Xu and Jia (1996) observed best callus result in the presence of 2, 4-D with Kin for Artemisia sphaerocephala.

Table.1: Influence of plant growth regulators concentrations on callus induction, relative water content (\%) of the Seriphidium herba-album via leaf explants after 35 days.

\begin{tabular}{|c|c|c|c|}
\hline \multicolumn{2}{|c|}{$\begin{array}{c}\text { Growth } \\
\text { regulators } \\
(\mathbf{m g} / \mathbf{l})\end{array}$} & $\begin{array}{c}\text { Callus induction } \\
\text { percentage }\end{array}$ & $\begin{array}{c}\text { Relative water } \\
\text { content } \\
\text { (RWC) }\end{array}$ \\
\cline { 1 - 2 } 2,4-D & BAP & & \\
\hline 1.0 & 0.0 & $42.92 \pm 0.31^{\mathrm{j}}$ & $42.50 \pm 0.62^{\mathrm{h}}$ \\
\hline 1.5 & 0.0 & $39.70 \pm 0.13^{\mathrm{k}}$ & $39.53 \pm 0.30^{\mathrm{i}}$ \\
\hline 2.0 & 0.0 & $40.84 \pm 0.52^{\mathrm{j}}$ & $36.30 \pm 0.84 \mathrm{j}$ \\
\hline 1.0 & 0.5 & $90.65 \pm 0.26^{\mathrm{c}}$ & $80.51 \pm 0.75^{\mathrm{c}}$ \\
\hline 1.0 & 1.0 & $83.70 \pm 0.75^{\mathrm{e}}$ & $78.51 \pm 0.92^{\mathrm{e}}$ \\
\hline 1.0 & 1.5 & $77.48 \pm 1.20^{\mathrm{i}}$ & $79.70 \pm 0.54^{\mathrm{d}}$ \\
\hline 1.5 & 0.5 & $95.44 \pm 0.30^{\mathrm{a}}$ & $75.60 \pm 0.55^{\mathrm{e}}$ \\
\hline 1.5 & 1.0 & $48.73 \pm 1.45^{\mathrm{h}}$ & $71.24 \pm 0.92^{\mathrm{g}}$ \\
\hline 1.5 & 1.5 & $63.56 \pm 0.93 \mathrm{~g}$ & $78.56 \pm 0.65^{\mathrm{e}}$ \\
\hline 2.0 & 0.5 & $92.48 \pm 0.82^{\mathrm{b}}$ & $81.35 \pm 1.28^{\mathrm{b}}$ \\
\hline 2.0 & 1.0 & $87.57 \pm 1.43^{\mathrm{d}}$ & $72.40 \pm 0.85^{\mathrm{f}}$ \\
\hline 2.0 & 1.5 & $79.90 \pm 0.49^{\mathrm{f}}$ & $83.72 \pm 0.45^{\mathrm{a}}$ \\
\hline
\end{tabular}

Values are presented by mean \pm SE Same letters represent no significant differences between means at $\mathrm{P} \leq 0.05$ level.

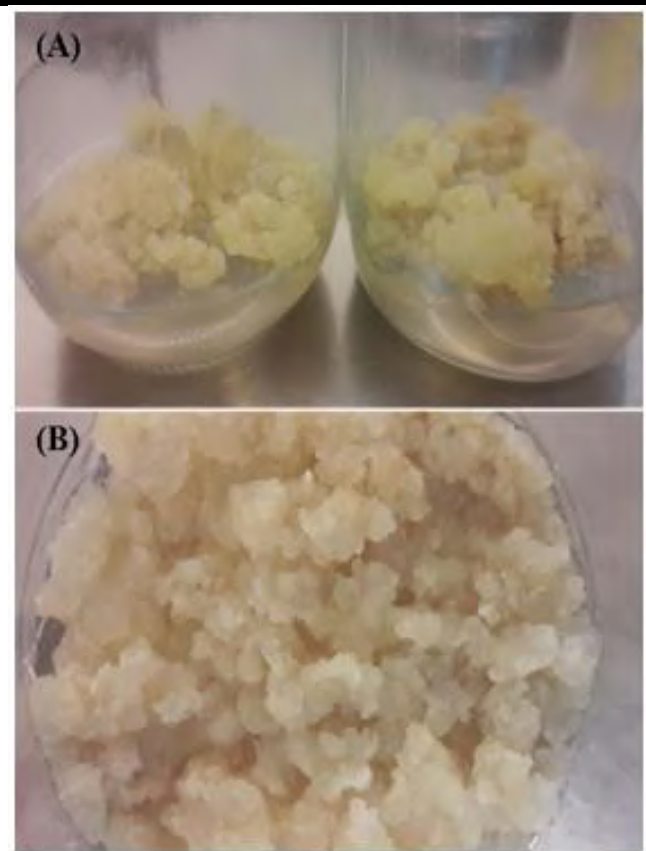

Fig.1: In vitro callus induction and Initiation of somatic embryogenesis from leaf explant of Seriphidium herbaalbum. (A): Induction of callus after 35 days on MS medium supplemented with $1.5 \mathrm{mg} \mathrm{L}^{-1}$ 2, 4-D and $0.5 \mathrm{mg}$

$L^{-1}$ BAP under dark regimes. (B): Induction of embryogenic callus after eight weeks on the surface of primary callus that was induced from callus cultured on MS medium supplemented with $5.0 \mathrm{mg} \mathrm{L}^{-1}$ BAP and 0.5 $m g L^{-1}$

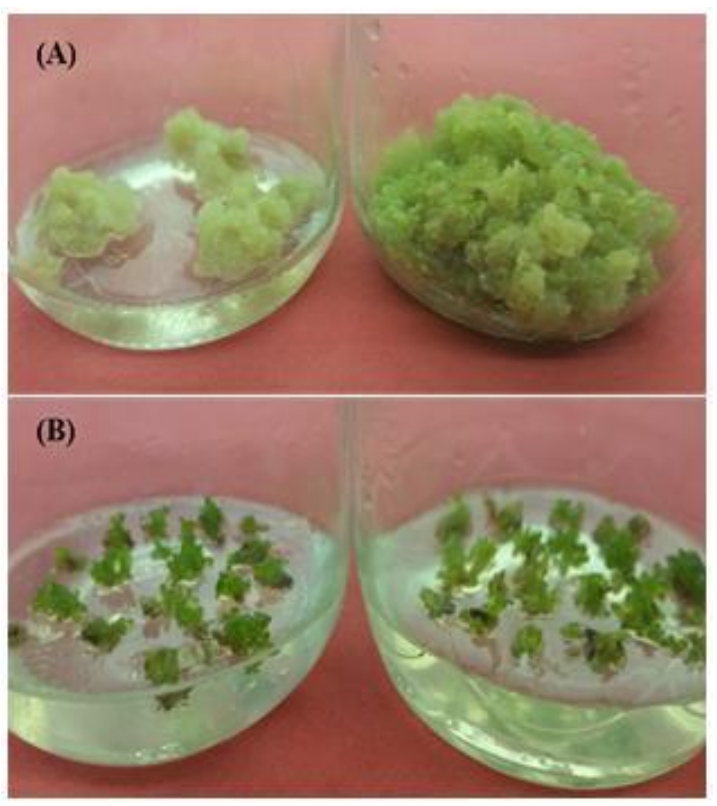

Fig. 2: Improved somatic embryo production and plant regeneration of Seriphidium herba-album. (A): Matured somatic embryos derived from callus cultured for eight weeks on MS containing with $5.0 \mathrm{mg} \mathrm{L}^{-1}$ BAP and $0.5 \mathrm{mg}$ $L^{-1}$ NAA under light.(B): small plant regeneration derived from callus cultured for four weeks on MS medium supplemented with $3.0 \mathrm{mg} \mathrm{L}^{-1} \mathrm{GA} 3$ and $0.5 \mathrm{mg} \mathrm{L}^{-1}$ kinetin. 
Somatic embryos and development of plantlets.

The percentage of somatic embryos formation of embryogenic callus were $95.30 \%$ with the average number of somatic embryos per $1.0 \mathrm{~g}$ fresh weight of embryogenic callus were 86.38 of Seriphidium herba-album. These observations were recorded on MS medium supplied by $5.0 \mathrm{mg} \mathrm{L} \mathrm{L}^{-1}$ BAP and $0.5 \mathrm{mg} \mathrm{L}^{-1}$ NAA (Table 2 and Fig. 1B). For further improvement and maturation of somatic embryogenesis, frequency of germination and conversion into plantlets, MS basal solid medium supported by GA3 at $\left(1.0-3.0 \mathrm{mg} \mathrm{L} \mathrm{L}^{-1}\right)$ in combination with kinetin (0.5-1.0 $\mathrm{mg} \mathrm{\textrm {L } ^ { - 1 }}$ ) were tested. The results in table 3 show that the somatic embryos germination percentage reached the highest value of $89.75 \%$ by using MS medium supplemented with $3.0 \mathrm{mg} \mathrm{L^{-1 }}$ GA3 and $1.0 \mathrm{mg} \mathrm{L}^{-1}$ Kinetin under light (Fig. 3A and B) compared with other treatments. Results also show that the mean number of shoots on the explant (5.87) treated with MS containing $3.0 \mathrm{mg} \mathrm{L}^{-1} \mathrm{GA} 3$ and $0.5 \mathrm{mg} \mathrm{L}^{-1}$ kinetin was significantly higher than the other treatments (Fig $\mathbf{3 A}$ and B). While, the best results of mean length of shoots formed per explant $(14.28 \mathrm{~mm})$ were produced on concentration of 3 mg L ${ }^{-1} \mathrm{GA} 3$ and $1.0 \mathrm{mg} \mathrm{L}^{-1}$ kinetin compared to the other treatments (Fig. 4A and $B$ ).

Table.2: Influence of plant growth regulators concentrations on percentage of somatic embryos formation /explant and average number of somatic embryos/ $1.0 \mathrm{~g}$ FW of callus of the Seriphidium herba-album after eight weeks.

\begin{tabular}{|c|c|c|c|}
\hline \multicolumn{2}{|c|}{ Growth regulators (mg/l) } & $\begin{array}{c}\text { Percentage of somatic } \\
\text { embryos formation } \\
\text { /explant }\end{array}$ & $\begin{array}{c}\text { Average number of } \\
\text { somatic embryos/ 1.0 } \\
\text { FW of callus }\end{array}$ \\
\hline 1.0 & NAA & $40.75 \pm 0.32^{\mathrm{k}}$ & $47.52 \pm 0.24^{\mathrm{i}}$ \\
\hline 2.0 & 0.0 & $48.56 \pm 0.54^{\mathrm{j}}$ & $49.08 \pm 0.72^{\mathrm{h}}$ \\
\hline 3.0 & 0.0 & $72.30 \pm 0.35^{\mathrm{g}}$ & $66.40 \pm 0.56^{\mathrm{e}}$ \\
\hline 4.0 & 0.0 & $83.82 \pm 0.45^{\mathrm{d}}$ & $72.80 \pm 0.25^{\mathrm{d}}$ \\
\hline 5.0 & 0.0 & $85.32 \pm 0.94^{\mathrm{c}}$ & $81.45 \pm 0.84^{\mathrm{b}}$ \\
\hline 1.0 & 0.5 & $76.46 \pm 0.25^{\mathrm{f}}$ & $52.34 \pm 0.33^{\mathrm{g}}$ \\
\hline 1.0 & 1.0 & $65.41 \pm 0.55^{\mathrm{i}}$ & $47.58 \pm 0.62^{\mathrm{i}}$ \\
\hline 2.0 & 0.5 & $79.75 \pm 1.40^{\mathrm{e}}$ & $66.92 \pm 0.48^{\mathrm{e}}$ \\
\hline 2.0 & 1.0 & $68.50 \pm 0.82^{\mathrm{h}}$ & $55.89 \pm 0.37^{\mathrm{f}}$ \\
\hline 3.0 & 0.5 & $80.40 \pm 0.19^{\mathrm{e}}$ & $72.59 \pm 0.65^{\mathrm{d}}$ \\
\hline 3.0 & 1.0 & $68.50 \pm 1.03^{\mathrm{h}}$ & $49.53 \pm 0.72^{\mathrm{h}}$ \\
\hline 4.0 & 0.5 & $87.80 \pm 0.42^{\mathrm{b}}$ & $82.44 \pm 0.55^{\mathrm{b}}$ \\
\hline 4.0 & 1.0 & $79.50 \pm 0.37^{\mathrm{e}}$ & $78.25 \pm 0.22^{\mathrm{c}}$ \\
\hline 5.0 & 0.5 & $95.30 \pm 0.52^{\mathrm{a}}$ & $86.38 \pm 0.98^{\mathrm{a}}$ \\
\hline 5.0 & 1.0 & $80.09 \pm 0.18^{\mathrm{e}}$ & $79.48 \pm 0.09^{\mathrm{c}}$ \\
\hline
\end{tabular}

Values are presented by mean \pm SE Same letters represent no significant differences between means at $\mathrm{P} \leq 0.05$ level. 


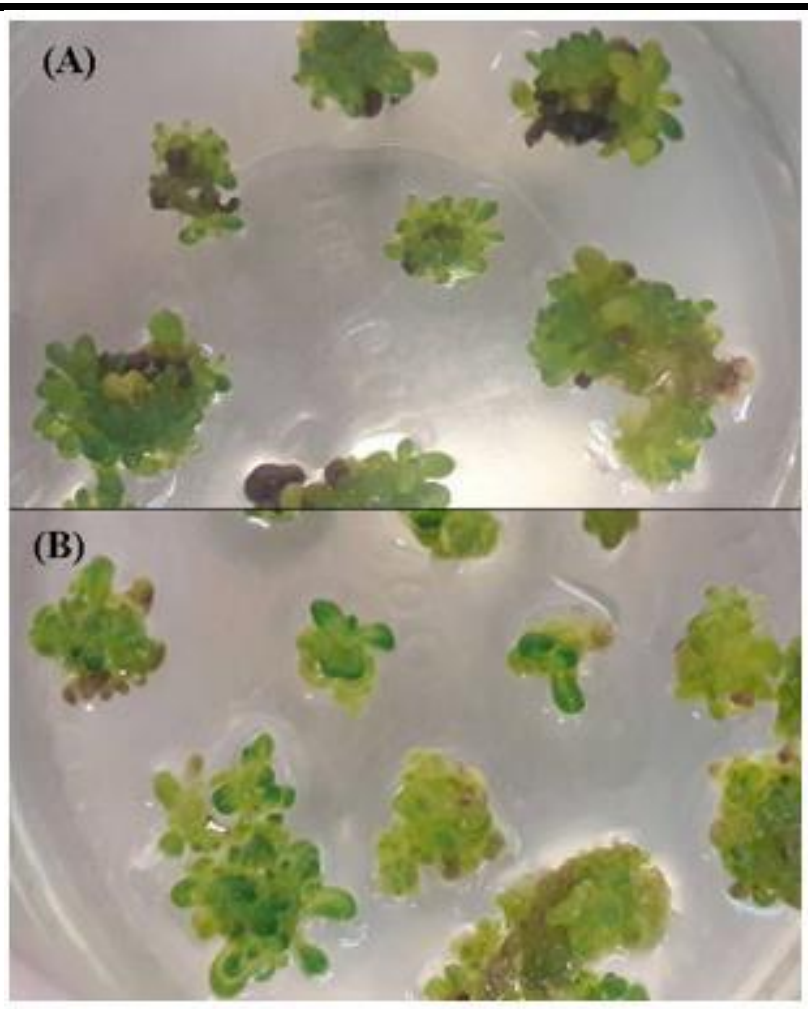

Fig. 3: In vitro plantlet obtained from a converted somatic embryo. (A): In vitro plantlet derived from matured somatic embryos cultured for eight weeks on MS containing with $3.0 \mathrm{mg} \mathrm{L}^{-1} \mathrm{GA} 3$ and $0.5 \mathrm{mg} \mathrm{L}^{-1}$ kinetin under light. (B): MS containing with $2.0 \mathrm{mg} \mathrm{L}^{-1} \mathrm{GA3}$ and $1.0 \mathrm{mg} \mathrm{L}^{-1}$ kinetin under light.
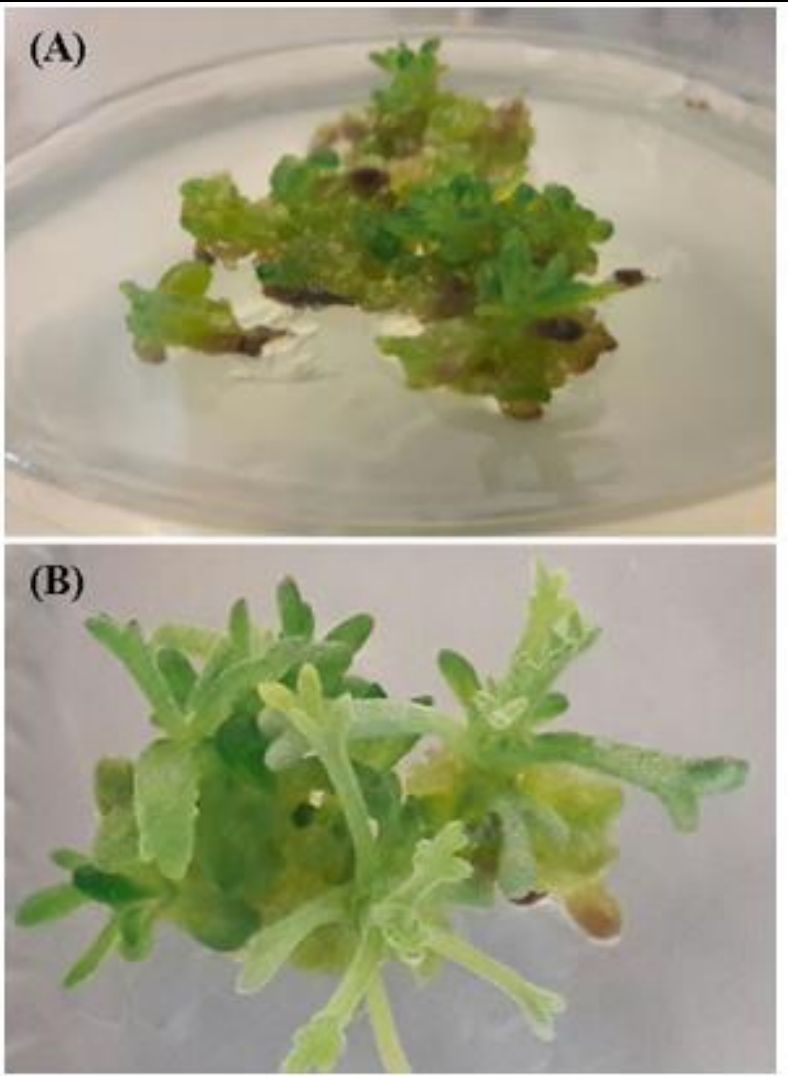

Fig. 4: Sub-culturing of somatic embryo on MS medium supplemented $5.0 \mathrm{mg} \mathrm{L}^{-1} \mathrm{BAP}$ and $0.5 \mathrm{mg} \mathrm{L}^{-1} \mathrm{NAA}$ under light $(A)$ and differentiated into multiple shoots and shoot elongation on $3.0 \mathrm{mg} \mathrm{L}^{-1} \mathrm{GA3}$ and $1.0 \mathrm{mg} \mathrm{L}^{-1}$ kinetin(B).

Table.3: Influence of plant growth regulators concentrations on somatic embryos germination percentage, average number of shoots/explant and mean shoot length of the Seriphidium herba-album after eight weeks.

\begin{tabular}{|c|c|c|c|c|}
\hline \multicolumn{2}{|c|}{$\begin{array}{c}\text { Growth regulators } \\
(\mathrm{mg} / \mathrm{l})\end{array}$} & \multirow{2}{*}{$\begin{array}{c}\text { Somatic embryos } \\
\text { germination }(\%) \\
\text { (germinated/embryos } \\
\text { tested) }\end{array}$} & \multirow{2}{*}{$\begin{array}{l}\text { Mean number } \\
\text { of } \\
\text { shoots/explant }\end{array}$} & \multirow{2}{*}{$\begin{array}{c}\text { Mean shoot } \\
\text { length } \\
(\mathrm{mm})\end{array}$} \\
\hline GA3 & Kn & & & \\
\hline 1.0 & 0.5 & $62.90 \pm 0.77^{f}$ & $3.54 \pm 0.28^{c}$ & $10.50 \pm 0.12^{\mathrm{e}}$ \\
\hline 1.0 & 1.0 & $68.83 \pm 0.95^{\mathrm{e}}$ & $3.76 \pm 0.09^{c}$ & $12.59 \pm 0.25^{\mathrm{c}}$ \\
\hline 2.0 & 0.5 & $78.35 \pm 0.65^{d}$ & $4.59 \pm 0.22^{b}$ & $10.30 \pm 0.16^{\mathrm{e}}$ \\
\hline 2.0 & 1.0 & $80.60 \pm 0.38^{c}$ & $4.89 \pm 0.34^{b}$ & $13.80 \pm 0.65^{b}$ \\
\hline 3.0 & 0.5 & $84.30 \pm 0.59^{b}$ & $5.87 \pm 0.25^{\mathrm{a}}$ & $11.75 \pm 1.02^{d}$ \\
\hline 3.0 & 1.0 & $89.75 \pm 0.62^{\mathrm{a}}$ & $4.95 \pm 0.17^{b}$ & $14.28 \pm 0.26^{\mathrm{a}}$ \\
\hline
\end{tabular}

Values are presented by mean \pm SE same letters represent no significant differences between means at $\mathrm{P} \leq 0.05$ level.

Similar observations were also made by several investigators in Artemisia annua L. plants (Gonzalez et al., 2013; Anis et al., 2014). Also, Vergauwe et al. (1996) reported the shoot regeneration from leaf explants of $A$. annua L. on MS medium with $0.05 \mathrm{mg} \mathrm{L}^{-1} \mathrm{NAA}$ and 0.05 mg L $\mathrm{L}^{-1}$ BAP after 5 weeks of culture. In the present study, a result of shoot induction rate is in agreement with the report of Dangash et al. (2015) who showed that the best shoot induction $83.6 \% \quad(2.83 \pm 0.234)$ was observed on BAP $\left(1.5 \mathrm{mg} \mathrm{L}^{-1}\right)$ in combination with NAA $\left(0.05 \mathrm{mg} \mathrm{L}^{-}\right.$ 1). At different concentrations of Kin alone or in combination with NAA response of shoot induction was observed low. At $1.0 \mathrm{mg} \mathrm{L}^{-1} \mathrm{Kin}$, shoot induction was $56.2 \%$. Also, Banyai et al. (2005) who considered 1mg/L 
BAP with $0.1 \mathrm{mg} / \mathrm{L}$ NAA as the best supplemented medium for leaf- explants-derived shoot regeneration. Almaarri and Yu Xie (2010) reported 100 and 66.6\% shoot induction in different genotypes of A. annua on MS fortified with TDZ $\left(1 \mathrm{mg} \mathrm{L^{-1 }}\right)$ and $\operatorname{BAP}\left(1 \mathrm{mg} \mathrm{L}^{-1}\right)$, respectively. Similar results have also been reported by (Sharma et al., 2008; Hailu et al. 2013). In vitro micro propagation and organogenesis of various Artemisia species have been previously established by using several explants in order to produce large number of plants, such as Artemisia vulgaris L (Sujatha and Rajnitha Kumari, 2007b), Artemisia annua (Ganesan and Paulsamy, 2011; Gopinath et al., 2014).

\section{CONCLUSION}

The different concentrations and combinations of PGRs, used in our study, were effective to induce calli, maturation of somatic embryogenesis, frequency of germination and conversion into plantlets. The combinations of 2,4-D and BAP supplemented medium induced friable calli in the leaf explants of Seriphidium herba-album. The creamish green calli with good growth were observed under dark regimes on MS medium supplemented with 2,4-D $\left(2 \mathrm{mg} \mathrm{L}^{-1}\right)$ and BAP $\left(1.5 \mathrm{mg} \mathrm{L^{- }}\right.$ 1). Somatic embryogenesis was induced from callus explant in presence of BAP and $\mathrm{Kn}$ as cytokinin. The regeneration system developed in this study will be useful for plant improvement through indirect somatic embryogenesis and genetic engineering of Seriphidium herba-album Moreover, this system can be available for the clonal propagation in order to obtain the strain containing a constant concentration of artemisinin in Seriphidium herba-album.

\section{ACKNOWLEDGMENTS}

The authors are thankful to the Tissue Culture and Biotechnology Labs., Maryout Research Station, Desert Research Center, Alexandria, Egypt.

\section{REFERENCES}

[1] Almaarri, K., Yu Xie 2010. In vitro direct organogenesis and micropropagation of Artemisia annua. $J$ Biotechnologie Vegetale, 26: 327-337. http://damasuniv.edu.sy/mag/farm/images/ stories/327-337 .pdf.

[2] Anis, M., Pravej, A., Malik, M. A., Athar, Ali., Javed, A., Abdin, M. Z. 2014. Impact of plant growth regulators (PGRs) on callogenesis and artemisinin content in Artemisia annua L. plants. Indian Journal of Biotechnology, Vol 13, January, pp 26-33.

https://doi.org/10.1080/17429145.2014.893030.
[3] Banyai, W., Nakamura, I., Mii, M., Supaibulwatana, K. 2005. High regeneration frequency of transgenic plants in Artemisia annua $L$. by Agrobacterium tumefaciens mediated gene transformation. Proceedings of the 10th international congress of SABRAO. 22-24 August 2005. The University of Tsukuba, Japan 2005.

[4] Ben Abid, Z., Moncef, F., Abderrazek, H., Mohamed, H. 2007. Artemisia herba-alba Asso. (Asteraceae) has equivalent effects to green and black tea decoctions on antioxidant processes and some metabolic parameters in rats. Annual Nutrition and Metabolism, 51:216-222. https://doi.org/10.1159/000104140.

[5] Benjamin, B.D., Sipahimalani, A.T., Heble, M.R. 1990. Tissue culture of Artemisia pallens: organogenesis, terpenoid production. Plant Cell Tissue Organ Cult., 21: 159-164. https://doi.org/10.1007/BF00033436.

[6] Boutkhil, S., E Idrissi, M., Chakir, S., Derraz, M., Amechrouq, A., Chbicheb, A., El Badaoui, K. 2011. Antibacterial and antifungal activity of extracts and essential oils of Seriphidium herba-alba (Asso.) Soják and their combination effects with the essential oils of Dysphania ambrosioides (L) Mosyakin \& Clemants, Acta Botanica Gallica, 158 (3): 425-433. https://doi.org/10.1080/12538078.2011.10516284.

[7] Dangash, A., Ram, M., Niranjan, R., Bharillya, A., Misra, H., Pandya,N., Jain, D.C. 2015. In vitro Selection and Hormonal Regulation in Cell Culture of Artemisia annua L. Plant. JSM Cell Dev Biol \& Developmental Biology, 3(1): 1013:1-7. http://dx.doi.org/10.15835/nsb639109.

[8] Essawi, T., Srour, M. (2000). Screening of some Palestinian medicinal plants for antibacterial activity. Journal of Ethnopharmacology, 70:343-349. https://doi.org/10.1016/S0378-8741(99)00187-7.

[9] Etienne, H., Berger, A., Carron, M.P. 1991. Water status of callus from Hevea brasiliensis during induction of somatic embryogenesis. Physiol. Plant., 82: 213-218.

[10] Feuerstein, I., Müller, D., Hubert, K., Danin, A., Segal, R. 1986. The constitution of essential oils from Artemisia herba alba populations of Israel and Sinai. Phytochemistry, $25 \quad$ (10): 2343-2347. https://doi.org/10.1016/S0031-9422(00)81692-1.

[11] Ganesan, C. M., Paulsamy, S. 2011. Standardized protocol for the in vitro culture of Artemisia annua L.-A medicinal plant at high altitudes of Nilgiris, the Western Ghats. J Res Biol.; 1: 173-178. http://jresearchbiology.com/documents/RA0057.pdf.

[12] Gonzalez, F.A., Perkins, K., Winston, M.I., Xie, D. 2013. Efficient Somatic Embryogenesis 
and Organogenesis of Self-Pollination Artemisia annua Progeny and Artemisinin Formation in Regenerated Plants. American J Plant Sci., 4: 22062217. http://dx.doi.org/10.4236/ajps.2013.411274.

[13] Gopinath, B., Gandhi, K., Saravanan, S. 2014. In vitro propagation of an important medicinal plant Artemisia annua L. from axillary bud explants. Advances in Applied Science Research, 5(1):254-258. http://dx.doi.org/10.3329/ptcb.v23i2.17518.

[14] Gulati, A., Bharel, S., Jain, S. K., Abdin, M. Z., Srivastawa, P. S. 1996. In vitro micropropagation and flowering in Artemisia annua. Journal of Plant Biochemistry and Biotechnology, 5: 31-35. https://doi.org/10.1007/BF03262976.

[15] Hailu, T., Abera, B., Mariam, E. G. 2013. In vitro mass propagation of Artemisia (Artemisia annua L.) CV: Anamed. Plant Tissue Cul \& Biotech., 23: 165-176. http://dx.doi.org/10.3329/ptcb.v23i2.17518.

[16] Honda, H., Liu, C. Z., Kobayashi, T. 2001. Largescale plant micropropagation. Advances in Biochemical Engineering/Biotechnology, 72: 157182. https://doi.org/10.1007/3-540-45302-4 6.

[17] Kour, B., Kour, G., Kaul, S. Dhar, M. K. 2014. In vitro mass multiplication and assessment of genetic stability of in vitro raised Artemisia absinthium L. plants using ISSR and SSAP molecular markers. Advances in Botany, 13(8): 1-7 http://dx.doi.org/10.1155/2014/727020.

[18] Liu, C. Z., Murch S. J., E-Demerdash, M., Saxena, P. K. 2004. Artemisia judaica L. micropropagation and antioxidant activity. $J$. Biotech., 110: 63-71. https://doi.org/10.1016/j.jbiotec.2004.01.011.

[19] Mahmoud, H. S., Mohamed, H. B., E-Baroty, G. 2007. Fungicidal activity of Artemisia herba-alba Asso. (Asteraceae). Journal of Environmental Science and Health, Part B. 41:237-244. https://doi.org/10.1080/03601230500354774.

[20] Mannan, A., Shaheen, N., Arshad, W., Qureshi, R. A., Zia, M., Mirza, B. 2008. Hairy roots induction and artemisinin analysis in Artemisia dubia and Artemisia indica. African. Journal of Biotechnology. $\quad$ 18: 32883292.https://doi.org/10.5897/AJB08.516.

[21] Nahla S. Abdel-Azim, Khaled A. Shams, Abdel Aaty A. Shahat, Moustafa M. El-Missiry, Shams I. Ismail, Faiza M. Hammouda 2011. Egyptian herbal drug industry: Challenges and future prospects. Research Journal of Medicinal Plant, 5(2):136-144. https://doi.org/10.3923/rimp.2011.136.144.

[22] Nin, S., Mosori, E, Schiff, S., Bennici, A. 1996. Callus cultures of Artemisia absinthium L. Initiation, growth optimization and organogenesis. Plant Cell Tissue Organ Culture. 45: 67-72. https://doi.org/10.1007/BF00043430.

[23] Pan, Z.G., Liu, C.Z., Murch S. J., E-Demerdash, M., Parveen, K. S. 2003. Plant regeneration from mesophyll protoplasts of the Egyptian medicinal plants Artemisia judaica L. and Echinops spinosissimus Turra. Plant science, 21(6): 525530.https://doi.org/10.1016/S0168-9452(03)00220-6.

[24] Rezvan, K. B., Mysore S. S., Mallappa, H. N. 2010. In vitro Plant Regeneration from Leaf Explants of Artemisia vulgaris L. - A Medicinal Herb. Modern Applied Science, 4 (9):130-134. http://dx.doi.org/10.5539/mas.v4n9p130.

[25] Segal, R., Feuerstein, I., Danin, A. 1987. Chemotypes of Artemisia herba-alba in Israel based on their sesquiterpene lactone and essential oil constitution. Biochemical Systematics and Ecology, 15, 411-416. https://doi.org/10.1016/03051978(87)90054-8.

[26] Sharma, A., Yadav, A. S., Bajaj, A., Rai, A. 2008. Cost effective in vitro micropropagation protocol for conservation of plant resources with special reference to important medicinal plants. J Env Res Dev.;2: 357-364. http://www.sciencedomain.org/review-history/5518

[27] Singh, A., Sarin, R. 2010. Artemisia scoparia - A new source of artemisinin. Bangladesh Pharmacological Society. 5(1): 17-20. http://dx.doi.org/10.3329/bjp.v5i1.4901.

[28] Snedecor, G.W., Cochran, W.G. 1982. Statistical Methods. 7th Edition, Iowa State University Press, Towa, 511. https://doi.org/ 10.2307/2530332.

[29] Sujatha, G., Rajnitha Kumari, B. D. 2007a. Highfrequency shoot multiplication in Artemisia vulgaris L. using thidiazuron. Plant Biotechnology Reports, 1 : 149-154. https://doi.org/10.1007/s 11816-007-0028-1.

[30] Sujatha, G., Rajnitha Kumari, B. D. 2007b. Effect of phyto-hormones on micropropagation of Artemisia vulgaris L. Acta Physiol. Plant. 29: 189-195. https://doi.org/10.1007/s 11738-006-0023-0.

[31] Vergauwe, A., Cammaert, R., Vandenberghe, D., Genetello, C., Inze, D., Van Montagu, M. 1996. Agrobacterium tumefaciens-mediated transformation of Artemisia annua L. And regeneration of transgenic plants. Plant Cell Rep., 15: 929-933. http://dx.doi.org/10.1007/BF00231590.

[32] Xu, Z.Q., Jia, J. F. 1996. Callus formation from protoplasts of Artemisia sphaerocephala Krasch and some factors influencing protoplast division. Plant Cell Tissue Org. Cult., 44: 129-134. http://link.s pringer.com/article/10.1007\%2FBF00048 $\underline{190}$. 